International Journal of Engineering \& Technology, 7 (2.29) (2018) 967-972
International Journal of Engineering \& Technology
SPC
Website: www.sciencepubco.com/index.php/IJET
Research paper

\title{
The Role of Diploma I Cadastral Surveying and Mapping Program in Fulfilling the Needs of Cadastral Surveyor Assistant in Indonesia
}

\author{
Nuraini Aisiyah $^{1 *}$, Kusmiarto ${ }^{2}$ \\ ${ }^{1,2}$ The National Land College STPN Yogyakarta, Indonesia \\ ${ }^{2}$ Gadjah Mada University, Yogyakarta, Indonesia \\ *Corresponding Author E-Mail: Aisiyahnuraini@Gmail.Com
}

\begin{abstract}
This paper aims to describe the role of Diploma I Cadastral Surveying and Mapping Program of National Land College (DI PPKSTPN) in fulfilling the needs of Cadastral Surveyor Assistant in Indonesia. DI PPK-STPN was established in 1996 in Yogyakarta with the aim to meet the needs of Cadastral Surveyor Assistant in Adjudication Program. Previously, in Indonesia, the candidate of Cadastral Surveyor Assistant was educated through the short course program. The method is descriptive, informative, which describes ability and competence owned by alumni of Diploma I PPK-STPN. Identification of the number of alumni of Diploma I PPKSTPN can describe the number of Cadastral Surveyor Assistant of Indonesia. By looking at the number of alumni of Diploma I PPKSTPN, we can see the level of adequacy of the needs of Cadastral Surveyor Assistant in the acceleration program of land registration in Indonesia. To achieve the ideal number of Cadastral Surveyor Assistant in Indonesia, the existence of DI PPK-STPN is still needed.
\end{abstract}

Keywords: Vocational Education; Cadastral Surveyor Assistant; Land Registration.

\section{Introduction}

\subsection{History of Cadastral Surveying and Mapping Pro- gram (DI PPK-STPN)}

Diploma I Cadastral Surveying and Mapping Program (DI PPKSTPN) was established in 1996, inaugurated by the Decree of the Minister of Agrarian Affairs / Head of National Land Agency No.12 of 1996, with the aim to respond to the demands of developments in the Land Affairs. The DI PPK-STPN is designed to meet the needs of Cadastral Surveyor Assistants. Each year the DI PPK-STPN graduates approximately 320 people. Until 2016, the number of alumni of DI PPK-STPN numbered 5239 people. A total of 2681 people have become civil servants in the Ministry of Agrarian and Spatial Planning/ National Land Agency (ATR/BPN), alumni who are not civil servants in the Ministry of ATR/BPN as many as 2558 people spread to Cadastral Surveyor Assistant, as civil servants in agencies other ATR/BPN, and in other private sector.

In the early stages of its founding in 1996-1997, in addition to regular formal education, the DI PPK-STPN has held a special education for Vocational High School (SMK) Surveying and Mapping graduates for 3 (three) periods in one year (four months for each period). There were 40 participants were trained in each training period. After completing the training, participants were licensed as Cadastral Surveyor Assistant. The objective at that time was to meet the needs of private companies that would participate in the tender for the Project of Land Administration Project (PAP) /Adjudication at BPN. Because of that time the re- quirement to participate in the tender, they (private companies) are required to have human resources that had a License of Cadastral Surveyor Assistant.

DI PPK-STPN is a formal education organized by the National Land College (STPN) under the Ministry of ATR/BPN. Learning System is the Semester Credit System (SKS). Based on current curriculum structure, the number of credits required to be reached is 43 credits, with a ratio of 16 credits of theory (37\%) and 27 credits of Practice (63\%) to be completed at least 2 (two) semesters and a maximum of 4 (four) semesters. 43 credits consist of Core Courses, Surveying and Mapping Courses, Law Courses and Land Registration Courses. The curriculum is reviewed and revised periodically in order to follow abreast of science and technology particularly Cadastral Surveying and Mapping. The title was given is Primary Expert and the graduates are entitled to the Cadastral Surveyor Assistant after being graduated following the License Examination held by the Sub- Directorates of Licensed Surveyor of the Ministry of ATR/BPN.

At first, in the learning process, the students carry out 2 (two) times Field Work Practice (PKL). PKL I was Ground Control Points Maintenance (in the first semester) and PKL II was Land Parcels Surveying and Mapping (in the second semester). Both PKL were carried out in the Village Laboratory in the Province of Yogyakarta Special Region, as one part of Community Service. Land Office (user) and Professional Organization (Indonesian Surveyor Association) are also involved in these PKL for supervision activity. The aim is that the User and Professional Organization gave input to this PKL activity for better improvement.

Considering the input from the Users (Land Office) and Stakeholders, in the latest revision of Curriculum (2016), these two 
PKLs are converted into Cadastral Surveying and Mapping Work Practices (KP PPK) conducted at the Land Office with a weight of 4 credits taken for approximately 2 (two) months, with the aim that the students of DI PPK get the learning experience of working practice/internship directly in the activity of collecting and processing data and examination conducted in the Land Office hopefully after graduation is expected to be more "ready to use". In the Work Practice, students must carry out the structuring activity ("structured internship") that is the collecting and processing of physical and juridical data. The collecting and processing of physical data contain Physical Data Collecting and Processing Practices First Land Registration, Land Registration Data Maintenance (Breaking, Separation and Merging of the boundary), Reconstruction of Parcel Boundary, Graphical Index Mapping, and Creating Registration Maps. All such activities must be passed and made a checklist. At the end of working practice activities, students must make work practice report.

\subsection{The Advantages and Challenges of DI PPK-STPN}

In the learning process of the DI PPK-STPN use the curriculum based on cadastral. The curriculum always follows the development of measurement technology and user needs. Recorded since its establishment, the DI-PPK's curriculum has been revised five times, in 2004, 2007, 2010, 2013 and 2016. At the end of the lesson, students are required to follow the Field Work Practice (PKL) Land Measurement in a village for 21 (twenty-one) days. The results of the PKL are Ground Control Points Map, Land Parcels Map, and Registration Base Map, and history of juridical landowner data. The results of this PKL were used for a land certification process of cooperation between Village Office and Land Office. The locations of PKL are spread in all districts in the Yogyakarta Special Region, which is determined by the Decree of the Governor of Yogyakarta Special Region. At the beginning, PKL is a form of community service activities, and starting in 2013 the PKL is included in the curriculum structure of 3 (three) SKS (Credits Semester System). In order for the alumni of DI PPKSTPN ready to use, then in 2016, PKL is replaced by Work Practice and Cadastral Surveying and Mapping (KP-PPK) by applying the students for 2 (two) months in The Land Office spread over 3 (three) Provinces in Java Island and 2 (two) provinces outside Java Island.

The target of Indonesian Government in the year 2025 all the land parcels in Indonesia must be mapped and registered (54 million of 90 million land parcels has not been registered). The realization is constrained by lack of human resource. The numbers of surveyor are not enough. Indonesian Government should review the Regulation No.33, 2016 about directing the assistant surveyors in the private sector that influenced the existence the Alumni of DI PPKSTPN.

Before the enactment of the Ministerial Regulation number 33 the year 2016 (1), which is entitled to take the license exam of cadastral surveyor assistant is only and must be graduated from DI PPK-STPN, but after the enactment of that regulation, it is not only the graduates of study program that has the opportunity to take the Cadastral Surveyor Assistant exam, but also the graduate of Vocational High School (SMK) that has followed the education and short training for 6 (six) months held by ministry of ATR/BPN can also take the license exam. This is a formidable challenge to the DI PPK-STPN to be able to maintain its existence and remain attractive to prospective students.

The purpose of this paper is to find out the competence of the Alumni of DI PPK-STPN as the strength in preparing human resources for acceleration of land registry.

\section{Literature Review}

\subsection{The Cadastral Surveyor Assistant}

Based on (1), The Licensed Cadastral Surveyor is the working partner of the Ministry of Agrarian Affairs and Spatial Planning/
National Land Agency (ATR/BPN) which was appointed and dismissed by the Minister of ATR/BPN, consisting of Cadastral Surveyors and Cadastral Surveyor Assistants.

Cadastral Surveyor is a person that has the expertise and skill in conducting the process of survey and mapping of land in the framework of land registration and absolute responsibility before the law for his or her surveying and mapping products product. Meanwhile, The Cadastral Surveyor Assistant is a skilled person in carrying out the process of land parcels surveying and mapping for land registration of the supervision of a Cadastral Surveyor and is responsible for his or her surveying and mapping products. The Licensed Cadastral Surveyor may take the form of Individual Business Entity or Business Entity Guild in the form of Firma. The Licensed Cadastral Surveyor Agency shall constitute Licensed Surveyor Service Office (KJSKB), consisting of Individual KJSKB and KJSKB Firma. Individual KJSKB is established by a Licensed Cadastral Surveyor who also acts as Leader, and consists of 1(one) Cadastral Surveyor and at least 1 (one) Assistant Cadastral Surveyor. The KJSKB Firm shall be established by at least 2 (two) Cadastral Surveyors, with one of the allies acting as the Leader of the partner, and consisting of at least 2 (two) Cadastral Surveyors and at least 2 (two) the Cadastral Surveyors Assistant. The scope of KJSKB's work includes survey and mapping planning, organizing and conducting surveys and mapping; and storage and management of documents resulting from the implementation of surveying and mapping work in the Protocol Book.

The Minister of ATR/BPN grants the license and appoints and dismisses the Cadastral Surveyor or Cadastral Surveyor Assistant. The licenses shall be granted to a validity period of 2 (two) years and may be extended for a further period of 5 (five) years periodically. Cadastral Surveyor or Cadastral Surveyor Assistant shall serve up to the age of 65 (sixty-five) years and may be extended 2 (two) times up to the age of 70 (seventy) years according to the request concerned. Candidates of Cadastral Surveyor and Cadastral Surveyor Assistant must pass the test held by the Ministry of ATR/BPN to be granted the license. The requirements for the examinations include a).Indonesian citizens; b).Undergraduate education (S1) studies program in the field of surveying and mapping, for Cadastral Surveyors; c).Vocational high school, Diploma I (D1) or Diploma III (D3) in surveying and mapping, for Cadastral Surveyor Assistant; d). Former ministry of ATR/BPN's employee that have worked for 20 years that have expertise in Cadastral surveying and mapping, for Cadastral Surveyors; e). Cadastral Surveyor Assistant who has worked 10 (ten) years continuously and actively to be appointed as Cadastral Surveyor; f). Have registered to become a member or has been a member of a professional association for surveyors in Indonesia. g). Have attended and passed the education and training (Short Course) of Cadastral Surveyors conducted by Ministry of ATR/BPN, Institute, high school, polytechnic or professional association; h).The election statement of the working area; and i). Complete administrative requirements. Cadastral Surveyor and Cadastral Surveyor Assistant have a working area within 1 (one) province.

The Minister of ATR/BPN may organize a short 6 (six) months education and training for candidate Cadastral Surveyor Assistant, to meet the needs of Cadastral Surveyor Assistant. The short education shall be held for 6 (six) months, at The Office of Ministry of ATR/BPN, Education and Training Center; National Land College (2), Regional Office of BPN, throughout Indonesia. The short educational requirements are at least graduated from High School or Vocational High School.

\subsection{Competency and Curricula of Cadastral Surveyor Assistant}

The Study of Surveying Curricula has been conducted by (3). He explained that the content of surveying curricula may vary from countries. Some general trends may be identified. There is clearly a trend towards an increased focus on managerial issues and the acquisition and application of interdisciplinary problem-solving skills. Regarding course delivery, there is a trend towards in- 
creased use of project-based education as well as skills for teamwork, cooperation, and communication and web-based learning tends to become an integrated tool for course delivery.

According to (4), The educational base must be flexible in order to deal with such significant change. Graduates must possess skills to be able to adapt to a rapidly changing labor market and they must utilize their skills to deal with the unknown problems of the future. According to (5), the "Minimal Curricula" concerns $50 \%$ of the total number of teaching hours. Detailed curricula of a faculty may comprise a bigger number of teaching hours as well as additiona subjects. Thematic contents and numbers of teaching hours of the "Minimal Curricula" are compulsory for professional recognition of graduates as surveyors with an academic qualification while applying for surveying to license.

According to (6), looking to the future of the profession, then, educational curricula must focus on four things. Firstly, the need to provide a foundation of general surveying and associated knowledge that has sufficient breadth to allow graduates to be able to read across sub-discipline areas with a reasonable measure of understanding. Specifically, in- depths learning should then be built upon this foundation. Secondly, they must encourage the development of good communication skills at all levels (written, verbal and graphics). Thirdly, they must engender within graduates the expectation that parts with the future professional life must include time for ongoing learning (both in a formal and an informal sense). Indeed, when graduates leave university it is essential that they do so with the expectation that this is not the end of their learning, but only a transition to a new phase. Finally, they need to convey to graduates the importance of professional structures and professional ethics. If all of the above can be achieved successfully, the issue of being practically competent on the first day of formal employment will become of minor importance.

According to (7), the professional surveying and mapping courses should be more "open-form" where a large range of scientific societal, legal, and economic issues are debated. Surveying and mapping programs need to find ways of networking with industry and government to supply needed current and detailed applications for the students. In return, the profession needs to create positive programs of assistance for schools to provide exposure to the newest methods. For example, internships or cooperative education, required as a part of a degree program, expose students to many detailed hands-on applications that cannot be taught in school. Equipment suppliers and manufacturers may place equipment in schools through grants or loan. Items to teach field operations may be leased or rent for use of school during a time period each year. Data sets from industry may be shared with schools for reduction and analysis.

Based on (8), there are 10 (ten) areas of surveying covered by at least one-half of the 14 ABET accredited professional level surveying programs studied: 1) Plane surveying; 2) Photogrammetry and Remote Sensing; 3) Surveying Computation; 4) Geodesy/GPS; 5) Cartography/Mapping; 6) GIS/LIS; 7) Cadastral/Boundary Surveying; 8) Land Subdivision; 9) Surveying Practicum/Camp; 10) Professional Issues.

Based on (9), new curricula in geo-informatics education have been established during the past few years. Their changes re-act new technological developments and needs of the society where the emphasis is on applications of environmental sciences, land management, urban planning, natural resource management etc. Graduates should have a good knowledge of theory and methodologies used in spatial data acquisition, processing, analyzing, and management. Nowadays learning does not end by graduating from a university. New graduates must keep their life-long knowledge up-to-date. This presents a challenge to universities as new courses re-acting recent research and development at both undergraduate and graduate levels are required by the student and professional geo-informatics community.

According to (10), DI PPK-STPN has been using a curriculum that teaches the 10 main surveying materials. Information Technology has not been integrated thoroughly into the curriculum in DI PPK-STPN. Field Work Practice (PKL) in the DI PPK-STPN is a form of project-based learning, problem-based, and scaffolding. The integration of academic-practitioner automatically has done by DI PPK-STPN. The challenges ahead for the program are meeting 139 competence subjects to the post of general functional existence, The Framework of The National Qualifications (KKNI) (11) (11) (11) ${ }^{11} 11$ [11] ("Regulation Of The President Of The Republic Of Indonesia Number 8 Year 2012 About National Qualification Framework Indonesia,") ("Regulation Of The President Of The Republic Of Indonesia Number 8 Year 2012 About National Qualification Framework Indonesia,") [11] ("Regulation Of The President Of The Republic Of Indonesia Number 8 Year 2012 About National Qualification Framework Indonesia,") [11] [11], and the presence of Cadastral 2014.

According to (12), concluded that the material taught and the antecedent learning methods of DI PPK-STPN has been in accordance with the criteria outlined in the Cadastral Surveyor Assistant regulations and DI PPK-STPN has the strength in the setup of human resources as the Cadastral Surveyor Assistants for the acceleration of land registry.

Based on The Indonesian National Qualification Framework KKNI (11), KKNI is the framework of competency qualification gap which can pair, match and integrate with the field of education and the field of job training as well work experience in the framework of giving competence recognition works in accordance with the structure of work in various sectors. Qualification Level of KKNI consists of a) Level 1 through 3 are grouped into operator positions; b) Level 4 to 6 are grouped in Technician or analyst positions; c) Level 7 to 9 are grouped into expert positions. Equalization of learning achievements generated through education with the qualification level in KKNI consisting of a) Basic education graduate is equivalent to level 1 ; b) The lowest secondary education graduate has equaled the level 2 ; c) Diploma 1 graduate is equivalent to level 3; d) Diploma 2 graduate is equivalent to level 4; e) Diploma 3 graduate is equivalent to level 5; f) Diploma 4 Graduate or Bachelor of Applied and Bachelor Degree is Equivalent to level 6; g) Graduates of the Applied Masters are equivalent to level $8 ; \mathrm{h}$ ) Applied Doctorate graduate and Doctorate equivalent to level 9; i) Professional education is equivalent to level 7 or 8 ; j) Specialist graduates education equivalent to level 8 or 9.

Based on these rules, DI PPK-STPN graduates are included in level 3 KKNI. The values according to the general description of level 3 of KKNI can be described as follows: a). Be able to carry out a series of specific tasks, by translating information and using tools, based on a number of procedural options work, and be able to demonstrate performance with quality and measurable quantity, which is partly the result of self-employment with indirect supervision; b). Have a complete operational knowledge, general principles and concepts related to the specific field of expertise, so to solve common problems with appropriate methods; c). Able to work together and communicate with the scope of work. Responsible can be given the quantity and quality of the work.

This paper is a review of previous writings further with an emphasis on the role of DI PPK-STPN more broadly.

\section{Methodology/Materials}

The methods used in this paper are descriptive, informative about the competence of DI PPK-STPN's alumni and the strength of DI PPK-STPN in preparing human resources.

\subsection{Competence of DI PPK-STPN's Alumni}

As a vocational classification of study, alumni of DI PPK-STPN with the level of education Diploma I, get the level of the national qualifications framework of level 3 (third level). Admission requirements are graduates of senior high schools (SMA) and pass the admission tests. The Language of Instruction is Bahasa Indonesia, the evaluation system uses marks $\mathrm{A}=4 ; \mathrm{A} / \mathrm{B}=3.5 ; \mathrm{B}=3$; $\mathrm{B} / \mathrm{C}=2.5 ; \mathrm{C}=2 ; \mathrm{C} / \mathrm{D}=1.5 ; \mathrm{D}=1 ; \mathrm{E}=0$ with a length of study is 1 (one) year and classification of further study is Diploma IV on Land Affairs. 
Based on Diploma Supplement as a complement explaining learning outcomes and achievements completed by the holder (DI PPKSTPN's alumni), the learning outcome of knowledge domains consists of understanding the methods of cadastral surveying and mapping, understanding administrative and legal aspects of land affairs and understanding communication skill.

The learning outcome of the general skill domain consists of being able to operate various kinds of surveying instruments for the purpose of cadastral surveying and mapping, performing cadastral surveying and mapping under supervision, having the capabilities of simple problem solving in cadastral surveying and mapping under supervision; showing integrity in carrying out tasks and being able to work in teams, being able to be responsible for delivering cadastral surveying and mapping product and being able to file documents of cadastral, surveying and mapping.

The learning outcome in specific skill domain consists of being able to carry out cadastral survey using terrestrial method and assisting photogrammetric and extraterrestrial works for land registration, being able to read and draw fieldwork documents, being able to carry out measurement of $4^{\text {th }}$ order Horizontal Ground Control Point (HGCP); being able to conduct mapping using Transverse Mercator $3^{\circ}$ coordinate system and carry out simple parcel boundaries reconstruction using terrestrial method, being able to understand basic land laws and land administration, being able to conduct measurement and mapping in various physical and natural condition and pressure and being able to carry out Graphical Index Mapping (GIM).

The competencies described above will largely depend on the curriculum used by DI PPK-STPN. The curriculum is formulated in accordance with the vision, mission, goals, and objectives. The curriculum is designed based on scientific substance, including surveying and mapping sciences and law and administration sciences. The curriculum related to surveying and mapping science is contained in the substance of the cadastral measurement and mapping subjects. The curriculum related to the field of law and administration is contained in the substance of the subjects of land registration.

Curriculum updating is based on stakeholder input by gathering input from stakeholders such as alumni tracer study and workshops or on other occasions that allow accommodating stakeholder suggestions. Curriculum development is also conducted to support the strategic programs of the Ministry of ATR/BPN, by making changes to the lecture unit or Syllabi related courses. In the Curriculum, there is a necessary assessment. Subsequent assessments are developed in the form of assessment guidelines on operations. In making the appraisal guidelines, the managing unit creates the guidelines. To ensure that appropriate assessment guidance is required, a review or workshop on such guidelines will be conducted. Furthermore, the management unit that prepares to be socialized for lecturers and students.

DI PPK-STPN is a vocational program, having a proportion of practice and theory, 63\%: 17\%. Practices are designed in three forms 1) practices related to lecture theory; 2) practices of combine knowledge, materials and character aspects, and 3) fieldwork practices. To integrate aspects of knowledge, materials and character aspects, then held the fieldwork practice (PKL) for two months in the land office

\subsection{The Strength of DI PPK-STPN in Preparing Hu- man Resources.}

Since 2016, DI PPK-STPN has begun to apply student-centered learning (SCL) methods. Learning is no longer a process of knowledge transfers from lecturers of students. As a consequence, learning by combining methods in addition to lectures also with discussions, tasks, presentations, cases, projects, etc., is important. Thus, it is expected that the curriculum can accommodate the objectives, targets, mission, and vision of the study program. In order to maintain the quality of education and learning DI PPKSTPN implements accreditation in accordance with the standards determined by the Higher Education National Accreditation Board
(BAN-PT). The year 2012 DI PPK-STPN accredited B and year 2016 Prodi DI PPK-STPN accredited A. There are 7 (seven) standards of assessed in the accreditation process, namely 1) Standard of Vision, Mission, Objectives, and Targets, Achievement Strategies. 2) Standard of Leadership, Management system, and Quality Assurance. 3) The Standard of Students and Graduates. 4) Standard Human Resources. 5) Standard of Curriculum, Learning, and Academic Atmosphere. 6) Standard of Financing, Facilities, Infrastructure, and Information Systems. 7) Standard Research, Service/Community Service, and Cooperation. The assessment of the seven standards is based on evidence and the assessment result of BAN-PT's assessor visited directly to DI PPK-STPN campus.

DI PPK-STPN has been using a curriculum that teaches the 10 (ten) main world surveying material. This is supported by a form of project-based learning, problem-based, and scaffolding so it can be said that the integration of academic-practitioner has performed at DI PPK-STPN. Until 2016, DI PPK-STPN already creates 5234 Alumni, 2681 works in Indonesian National Land Agency (BPN), and 2553 works as Cadastral Surveyors Assistants or private sector.

\section{Results and Findings}

Based on $(13,14)$, the Ministry of ATR/BPN has launched 3 (three) strategic programs during 2016 to 2019 are: 1) Acceleration of Asset Legalization systematically as much as 23.21 million plots of land; 2) Acceleration of Land Procurement to support the strategic development program, for example 35,000MW Power Station, 7.338Km Toll Road, 24 Airports, 3.258 Km Train Track, 24 Ports, 5 Million Units of Low-Income Communities (MBR), 49 Reservoirs, 1 million hectares of irrigation networks, 12 Special Economic Zones, 15 Industrial Zones, 78 Units of Gas Fuel Station and 2 Oil Refineries; 3) Implementation of Agrarian Reform with a target of 0.6 million hectares of transmigration lands that have not been certified, 3.9 million hectares of legalization of community assets, 0.4 million hectares of abandoned land, and 4.1 million hectares of land of forest disposal.

Based on Land Office Application data, accessed from (15) accessed on August 7th, 2016, of the total land parcels in Indonesia (90,622,523 land parcels), 41,800,133 (46\% of the land parcels) were registered and 48,822,390 land parcels (54\% of land parcels) that have not been registered. On the other hand, the current condition of the number of land surveyor the status as civil servants in the Ministry of ATR/BPN are as many as 2159 Persons. Meanwhile, the Licensed Surveyor consisting of 151 Land Surveyors and 2039 Land Surveyor Assistants, so that the total number of all BPN's surveyor and Licensed Surveyors is 4,349 people. The number of measuring officers of the Ministry of Agrarian Affairs and Spatial / National Land Agency on average only able to carry out land registration throughout Indonesia of approximately 1.5 million per year. In order to fulfill the strategic program target of land certification of 23.21 million fields within 3 years (20162019), the Ministry of ATR/BPN should be able to certify the plot of land as much as 7.73 million per year. A remarkable acceleration challenge must be answered. One of the steps that can be done is to speed up the addition of surveyor. Because until 2017 in the Ministry of ATR/BPN there is still a moratorium on the civil servant's recruitment, so that can be done is to accelerate the addition of non-civil servant/Licensed Surveyor. The Procurement of Licensed Surveyors, especially Land Surveyor Assistant has been done through the recruitment / License Examination for the graduates of DI PPK-STPN with an average of 320 per year. The amount is of course very less to meet the needs of acceleration of measurement of the framework of Land Registration in accordance with which has become the priority program.

The following is the formula used to calculate the completion time of all parcels of land that have not been registered throughout Indonesia: 
$\mathrm{T}=\frac{\mathrm{L}}{\mathrm{S} \times \mathrm{PD}} \times 200$

T: Completion Time (year)

L: Number of Unregistered Land

S: Number of Surveyor

PD: The average number of the land parcel measured by a surveyor per day

(Sporadic System: 5 parcels per day, Systematic System: 15 Parcels per day)

200: The assumption of working days per year

If the number of BPN's surveyors is 2159 and the number of Cadastral Surveyors Assistants is 2553, the target of 54 million land parcels and the implementation of sporadic land registrations, measured by the capability of surveyor 5 land parcels a day and the finishing targets are 5 million land parcels a year and the assumption of 200 working days, it will be finished in 12 years. Next, if the number of BPN's surveyors is 2159 and the number of Cadastral Surveyors Assistants are 2553 the target of 54 million land parcels and the implementation of systematic land registry, measured by the capability of surveyor 15 land parcels a day and the finishing targets are 5 million land parcels a year and the assumption of 200 working days, it will be finished in 4 years. The conclusion is if we are empowering the alumni of Diploma $1 \mathrm{Ca}$ dastral and Survey Mapping Program as Cadastral Surveyors Assistants and implementing the Systematic Land Registry, the finishing of the target could be accelerated 6 times (4 years) compared by not using Cadastral Surveyor Assistants (25 years).

The alumni of DI PPK-STPN have the competence as a Cadastral Surveyor Assistant. If all alumni of DI PPK-STPN are empowered, as a government officer or as a Cadastral Surveyor Assistant, the acceleration of the land registration in mapping sector will be realized in 2021.

To know the competencies of DI PPK-SPN alumni is explained by the contents of the 16 (sixteen) courses of the curriculum structure, the syllabi of each course are described as follows:

The contents of syllabi of Religious Education are in accordance with their respective religions for the development of character Assistant Land Surveyors who believe and piety to God Almighty.

1. The contents of syllabi of Pancasila and Civic Education are 1) Principles and History of National Struggle; 2) Pancasila as the ideal basis of the Indonesian nation and tongue as a Source of Law and Human Rights; 3) The values of Pancasila and the practice and appreciation. 4). Rights and Duties As a citizen; 5) Democracy Pancasila 6). Soul and Spirit of Nationalism.

2. The contents of syllabi of Applied Mathematics are 1) The Geometrics and Trigonometry for Surveyor; 2) Matrix and its Application; 3) Differential and Its Application; 4) Area Calculation Methods; 5) The Concept of Errors and Belief in Measurement; 6) Blunder Detection; 7) Weight In Measurement Systemic and Random Error Propagation.

3. The contents of syllabi of Cartography are 1) The Introduction to Cartography; 2) Map projection, Scale and Presentation Method; 3) Map Design, Symbolization, and Generalization; 4) Topographic Map; 5) Thematic Map; 6) Digital Cartography.

4. The contents of syllabi of Land Surveying are: 1) Introduction to Land Surveying; 2) Measurement of Angles; 3) Distance Measurement; 4) Leveling; 5) Closed Polygons; 6) Open polygon; 7) Angle Measurement; 8) Water-passing; 9) Measurement and Situation Mapping.

5. The contents of syllabi of Computer Data Processing are 1) Introduction to Computer Data Processing; 2) Use of MS Excel for Data Processing; 3) Use of Microsoft Access for Land Database Creation; 4) Introduction of AutoCAD Software; 5) AutoCAD Software for Ground Control Points Mapping; 6) AutoCAD Software for boundary parcels drawing; 7) AutoCAD Software for Map Layout; 8) Cadastral Data Management.

6. The contents of syllabi of Photogrammetry are 1) Introduction to Photogrammetry; 2) Geometry: Aerial Photo and
Satellite Imagery; 3) Photogrammetry Application in Cadastral Field; 4) Introduction to Software to Download Satellite Imagery from Various Sources; 5) Creating a Basic Map with Satellite Imagery; 6) Photogrammetric Mapping.

7. The contents of syllabi of Surveying Instrument Practices are 1) The Practice of Theodolite; 2) The Practice of Digital Theodolite; 3) The Practice of Water-pass; 4) The Practice of Distometer; 5) Total Station Usage Practices; 6) The Practice of Handheld GPS; 7) The Practice of Geodetic GPS; 8) The Practice of GNSS-CORS.

8. The contents of syllabi of Land Law are 1) Land Law and Agrarian Law; 2) The Right to Control the State and the Right to Manage; 3) Land Status; 4) Land Rights Before and After Law No. 5 of 1960 (UUPA); 5) Strata Title; 6) Land Banking and Land of Waqf.

9. The contents of syllabi of Professional Ethics are 1) Position, Main Task, and Function of Cadastral Surveyor Assistant; 2) Rights and Duties, Norms, and Code of Ethics Cadastral Surveyor Assistant; 3) Cadastral Surveyor Assistant As a Profession; 4) Cadastral Surveying and Mapping for Legal Assurance Guarantees; 5) The Responsibility for Cadastral Surveyor Assistant; 6) Communication in Service as a Professional Cadastral Surveyor Assistant.

10. The contents of syllabi of Land Registry are 1) Introduction to Land Registry; 2) Fundamentals of Land Registry; 3) Land Registration System; 4) Evidence Rights; 5) Research the History of the Land; 6) Land Registry for the First Time; 7) Procedures for Application Service Land Rights; 8) Procedure for Measuring Parcel Service; 9) Procedure for Solving Service, separation, merger Parcel.

11. The contents of syllabi of Digital Mapping are 1) Spatial Data Standard Concepts; 2) Map digitization; 3) Introduction to Geo-KKP; 4) Coordinate and Layer Standards; 5) Standard Annotation and Topology; 6); Introduction to ArcGIS and QGIS; 7) Convert AutoCAD Data to ArcGIS and QGIS; 8) Textual and Spatial Data Link; 9) Presentation of Thematic Land Map.

12. The contents of syllabi of Ground Control Point (GCP) are 1) Basic Concepts and GPC Classification; 2) Projection $\mathrm{TM}^{\circ}$; 3) Coordinate Count on $\mathrm{TM}^{\circ} \square$ 4) Coordinate Transformation; 5) Operation of GCP and Geodetic Measurement Methods; 6) Surveying and Mapping of GCP; 7) Global Navigation Satellite System (GNSS); 8) GNSS application; 9) Quality Control.

13. The contents of syllabi of Cadastral Surveying are 1) Introduction to the Cadastral Survey; 2) Measurement Procedure in Systematic and Sporadic Registration; 3) Measurement Methods; 4) Making of Land Registration Map; 5) The technique of measuring the separation and Merging of Land Parcel; 6) Mapping the Graphics Index; 7) Thematic Surveying and Mapping; 8) Preparation of Measurement Letters and Drawings.

14. The contents of syllabi of Measurement Documents Course are 1) Introduction to Measurement Documents; 2) Symbols of the Measurements Documents; 3) Preparation of Analog Measuring Instrument and Digital Measuring Instrument; 4) Measurements Documents for Various Area of Land Parcels; 5) Measurement Documents with Photo / Satellite Imagery; 6) Measurements Documents Scaled Drawing; 7) Measurement Documents Administration; 8) Methods and Techniques of Land boundary Reconstruction; 9) Alternative The Land Boundary Reconstruction with Other Documents.

15. The contents of syllabi of Cadastral Surveying and Mapping Practice are 1) The Practice of Collection and Processing of Physical Data; 2) Juridical Data Collection and Processing Practices; 3) Making the Report on Practices.

The Syllabi of each course described above is used as a guide in learning and teaching activities. Assessment of learning outcomes, evaluation of learning outcomes and making test questions should also be guided by the syllabi. This can be seen whether the process 
of learning and teaching has reached its goal. With the achievement of learning objectives, it is expected that the competence of DI PPK-STPN graduates in accordance with the competence of Cadastral Surveyor Assistant candidate.

\section{Conclusion}

Diploma 1 Cadastral Surveying and Mapping Program of National Land College (DI PPK-STPN) has big roles in supporting the acceleration of land registration in mapping the land parcels. The acceleration of the land registration will be realized in 2021 if the alumni of Diploma 1 Cadastral Surveying and Mapping Program as a Cadastral Surveyor Assistants are empowered and the government implements the Systematic Land Registration.

\section{Acknowledgement}

This work is supported by the National Land College (2) Yogyakarta, Indonesia.

\section{References}

[1] ATR/BPN. Regulation of The Minister of Agrarian and Spatial Planning/National Land Agency Number 33 Year 2016 About Licensed Cadastral Surveyor. 2016.

[2] STPN. Decision Letter of STPN Chairman on Curriculum and Syllabus of Diploma I Cadastral Surveying and Mapping Program. 2016.

[3] Enemark S. International Trends in Surveying Education. FIG XXII International Congress Washington, DC USA. 2002(Virtual Academy and Curricula Contents).

[4] Enemark S. Innovation in Surveying Education. Conference Proceedings of the 5th UICEE Annual Conference on Engineering Education. 2002(Student-centred Engineering Education).

[5] Czarnecki K. The "Minimal Surveying Curricula" - A Step towards Standardisation of Surveyor's Education in Poland. FIG International Congress. 2002;XXII (Surveying Core Curriculum).

[6] J. Hannah JK, R. Mahoney and F. Plimmer4. Surveying: A Profession Facing a Global Crisis? European Congress of Surveyors 2008 Strasbourg. 2008(The Perspectives - the role of the surveyor in the European society and economy).

[7] Rouch JJ, editor Summary of Models of Surveying Curricula Around The World FIG Working Week; 2000; Prague: International Federation of Surveyor (FIG); 2000.

[8] Frank S. US Surveying and Mapping Education Core Curricula FIG XXII International Congress, Washington, DC USA, 2002(Surveying Core Curriculum).

[9] Potuckova M. Trends in Geoinformatics Education. Geoinformatics FCE CTU. 2006

[10] Arief Syaifullah NA. Surveyor Education Global Trend: Diploma I Cadastral Surveying and Mapping At National Land College (STPN). 2013

[11] Regulation Of The President Of The Republic Of Indonesia Number 8 Year 2012 About National Qualification Framework Indonesia. 2012

[12] Aisiyah N. Peran Program Diploma I Pengukuran dan Pemetaan Kadastral dalam mencetak Asisten Surveyor Pertanahan (ASP) untuk mendukung Percepatan Pendaftaran Tanah. 2016.

[13] ATR/KaBPN M. Naskah Pidato Menteri Agraria dan Tata Ruang / Kepala Badan Pertanahan Nasional (ATR / BPN) Dalam Rangka Peringatan HUT ke-56 Undang-Undang Pokok Agraria pada tanggal 24 September 2016. 2016;Jakarta.

[14] ATR/KaBPN Mo. Speech of the Minister of Agrarian Affairs and Spatial / Head of the National Land Agency (ATR / BPN) in the Framework of the Commemoration of the 56th Anniversary of the Basic Agrarian Law on September 24, 2016. Jakarta. 2016;Jakarta.

[15] www.bpn.go.id. Official Website of Ministry of Agrarian Affairs and Spatial Planning/National Land Agency (ATR/BPN). 2016; November 10th, 2016. 